\title{
異時性多発舌癌に合併した同時性多発
}

食道表在癌の一例

$\begin{array}{llll}\text { 輿石 晴也*, 吉田 操**, 荒井 } & \text { 邦吉** } \\ \text { 岩塚 迪雄**, 加藤久美子***, 望月 } & \text { 真**** } \\ \text { 小池 盛雄****, 小宮 善昭*****, 輿石 義彦* }\end{array}$

\section{A Case of the Synchronous Multiple Esophageal Carcinoma with the Metachronous Multiple Tongue Carcinoma}

\author{
Haruya Koshiishi, M.D., ${ }^{*}$ Misao Yoshida, M.D., ${ }^{* *}$ \\ Kuniyoshi Arai, M.D., ${ }^{* *}$ Michio Iwatsuka, M.D., ${ }^{* *}$ \\ Kumiko Katoh, M.D., ${ }^{* * *}$ Makoto Mochizuki, M.D., ${ }^{* * * *}$ \\ Morio Koike, M.D., ${ }^{* * * *}$ Yoshiaki Komiya, M.D., ${ }^{* * * * *}$ \\ and Yoshihiko Koshiishi, M.D.* \\ *Department of Surgery, Tokyo Metropolitan Komagome Hospital, Tokyo and Tokyo \\ Medical College, ${ }^{* *}$ Department of Surgery, ${ }^{* * *}$ Department of Internal Medicine, \\ ****Department of Pathology, and ${ }^{* * * * *}$ Department of Oral Surgery, \\ Tokyo Metropolitan Komagome Hospital, Tokyo
}

Incidence of esophageal cancer among patients with head and neck cancer was estimated as about $1 \%$. Recently, we had a rare case with double cancer of metachronous multiple tongue cancer and synchronous multiple superficial esophageal cancer.

A 48 year old man admitted the hospital for his tongue ulcer. He had underwent partial resection and irradiation of tongue cancer 4 years before. Further examination revealed epidermoid carcinoma at tongue ulcer and multiple superficial esophageal cancer. The tongue cancer was estimated as metachronous multiple cancer, because the lesion occupied opposite side of the tongue to the former tumor and there suspected no continuity between them. Partial resection of the tongue and total thoracic esophagectomy were carried out. Histological studies on resected specimens disclosed the tongue cancer as T1N0 (stage I) and five esophageal cancers as superficial cancer ( 3 mucosal cancers, and 2 submucosal cancers). There found only one lymphnode metastasis at para-tracheal node $(n=1 / 98)$.

Postoperative chemotherapy was carried out using CDDP $50 \mathrm{mg}$, MTX $30 \mathrm{mg}$ and BLM $15 \mathrm{mg}$, and it repeated four times. Post operative course was uneventful.

Key words : 多発舌癌, 多発食道表在癌, 重複癌, 食道内視鏡

*都立駒込病院外科 (現東京医科大学外科), **都立駒 込病院外科, ***同内科, ****同病理科, *****同口 腔外科

別刷請求： $=170$ 東京都豊島区南大塚1-5-7 塞石晴也

投稿受付：1987年12月 4 日
はじめに

頭頸部領域癌と食道癌は，比較的頻度の多い ことが知られており，その診断，治療に際して は，関係各科の協力が必要である。最近われわ れは舌癌の切除, 照射療法後に, 異時性多発舌 
癌が発生し，その時の食道内視鏡検査で，多発 食道表在癌が発見された症例を経験したので報 告する。

\section{症例}

症 例：48歳, 男性, 飲食店経営者

主 訴：舌の難治性潰瘍

家族歴：特記すべきことなし

既往歴：1983年 3 月，左側舌癌にて切除術 (T2N0= stage II，扁平上皮癌)，および術後照 射(左右対向 2 門照射 $2000 \mathrm{rad}, 8 \mathrm{mg} \mathrm{Ra}$ 針 120 時間組織内照射)。

嗜好品：飲酒 $5 \sim 7$ 合/日 $\times 20$ 年間 喫煙 30 本/日 $\times 20$ 年間

現病歴：1986年 2 月, 舌右側の難治性潰瘍が 出現, 舌癌と診断され, 同年 5 月当院口腔外科 へ入院した。

診断および治療経過：理学的所見では，舌右 側に約 $10 \mathrm{~mm}$ の溝状潰瘍があり，周囲は硬結 していた(図 1)。舌左側は軽く陥凹して瘢痕を 形成していた。今回の舌病巣は, 前回舌病巣と は反対側であり，連続性も認められないため， 異時性多発舌癌と診断した。

食道透視では, 3 力所に病変を認めた(図 2$) 。$ $\mathrm{Iu}$ に $2.5 \mathrm{~cm}$ の壁の不整と, 顆粒状の隆起があ り, Ei には $1.5 \mathrm{~cm}$ の壁の不整像があり, Iu から Eiにかけて壁の不整像と，その中央やや肛門側 に低い不整な隆起が認められた。表在型多発食 道癌と診断された。

内視鏡検查では，トルイジンブルーヨード二 重染色法により, 5 力所に病変を認めた（図 3 )。 病変 $\mathrm{A}$ は, 切歯より $23 \mathrm{~cm}$ で, 後壁中心約半周 に表面凹凸不整な不染帯を認め，混合型表在癌 と診断された。B，Cは，切歯より $28 \mathrm{~cm} て ゙ ，$ 前壁と左側壁に表面の平坦な不染体 2 力所を認 め, 平坦型表在癌と診断された。 $\mathrm{D}$ は，切歯よ り $31 \mathrm{~cm}$ で, 前壁から左側壁にかけて表面平坦 な不染帯を認め, 平坦型表在癌と診断した。 $\mathrm{E}$ は，切歯より $35 \mathrm{~cm}$ で，左側壁中心に表面凹凸 不整な不染体を認め, 混合型表在癌と診断され た。Biopsy の結果は，中分化から高分化の扁平 上皮癌であった。

手術所見：舌癌と表在型多発食道癌の診断 で，1986年 7 月 1 日舌部分切除，右開胸開腹胸
腔内食道全摘，胸骨前食道胃吻合，両側頸部郭 清術を施行した。局所所見は, A0N0P10M0= stage I， R III，C IIIであった。

病理診断：食道切除標本（図 4) では, 右端 の口側断端より約 $2 \mathrm{~cm}$ 左側下半分に白色調の 低い不整な隆起を認め, 約 $9 \mathrm{~cm}$ 左側全体に白 色調の不整な低い隆起を認め, 約 $12 \mathrm{~cm}$ 左側中 央に白色調の中央陥凹した不整な隆起を認め た。ヨード染色標本所見では，生標本でみられ た病変は不染帯として観察され，それ以外に右 端口側断端より約 $6 \mathrm{~cm}$ 左側中央に, 小さい不 染帯が 2 力所認められた（図 5 )。

結局病変は 5 つ独立に存在し, 分化度の異な る扁平上皮癌で，いずれの墚達度も粘膜下層ま でにとどまっており，多発性食道表在癌と診断 された (図 5 , 図 6a〜d)。また，右傍気管リン パ節 No106に 1 個転移があり，(1/98） $\mathrm{a}_{0} \mathrm{n}_{2} \mathrm{pl}_{0}$ $\mathrm{m}_{0}=$ stage IIIであった。

舌癌は高分化扁平上皮癌で, $\mathrm{T} 1 \mathrm{~N} 0=$ stage I であった。

経 過：経過は良好で, 術後補助化学療法 (CDDP $50 \mathrm{mg}+$ MTX $30 \mathrm{mg}+$ BLM $15 \mathrm{mg}$ ) を 4 回施行し退院した。

\section{考按}

口腔, 咽頭, 喉頭領域 (以後 OPL と略す) と, 食道の重複癌については種々の報告がある。 Cahan $ら^{11}$ は, 約7,000例の OPL 癌患者のうち 60例， $0.9 \%$ が食道癌を重複したと報告してお り，川本ら ${ }^{2)}$ は2,802例の OPL 癌患者のうち 35 例， $1.2 \%$ が食道癌を重複したと報告している。 川本らはこのうち舌口腔癌では959例中 9 例, $0.9 \%$ に食道癌を重複したと報告している。

一方阿保ら ${ }^{3)}$ は, 11,732 例の食道癌のうち 26 例， $0.2 \%$ が舌口腔癌を重複したと報告してお り, 喜多ら ${ }^{4)}$ は, 1,904例の食道癌のうち22例, $1.2 \%$ OP OPL 癌を重複したと報告しており，こ

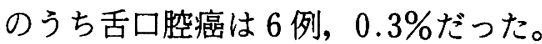

したがって, OPL 癌と食道癌の重複は約 $1 \%$ と決して稀でないため, OPL 癌患者に対する食 道精査, また食道癌患者に対する頭頸部領域へ の診察の重要性が指摘されている。

食道癌の多発癌については, 井手ら ${ }^{5)}$ は食道 癌切除例 977 例中 41 例, $4.2 \%$ に多発癌を認めた 


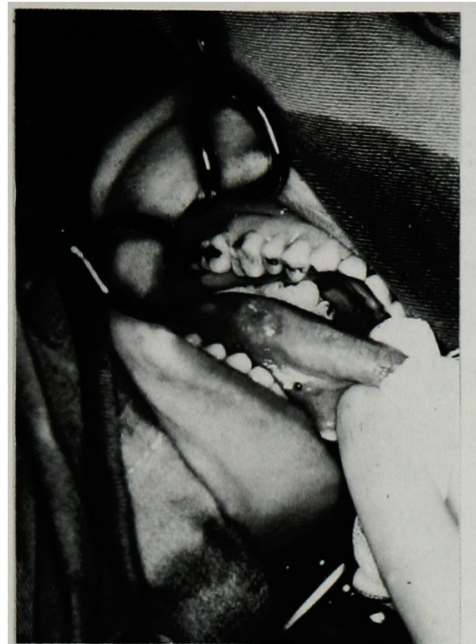

図 1 舌癌

舌右側の溝状潰瘍が認められる。

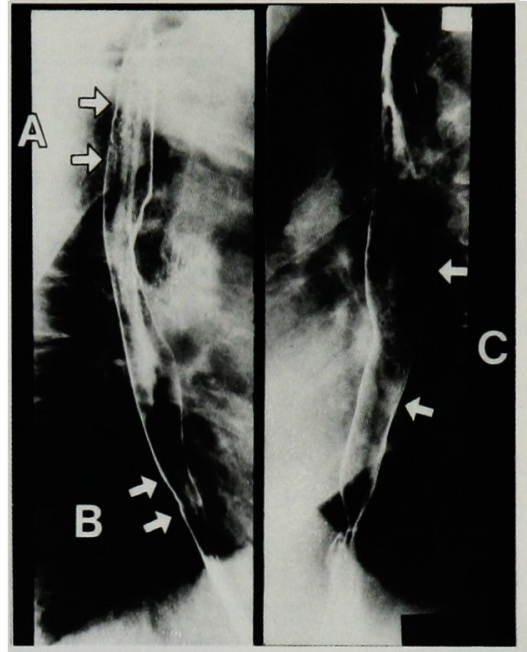

図 2 食道透視

A：Iuの壁不整像，B：Eiの壁不整像,

$\mathrm{C} ： \mathrm{I} u \sim \mathrm{E} \mathrm{i} の$ 壁不整像と，低い不整な隆起。

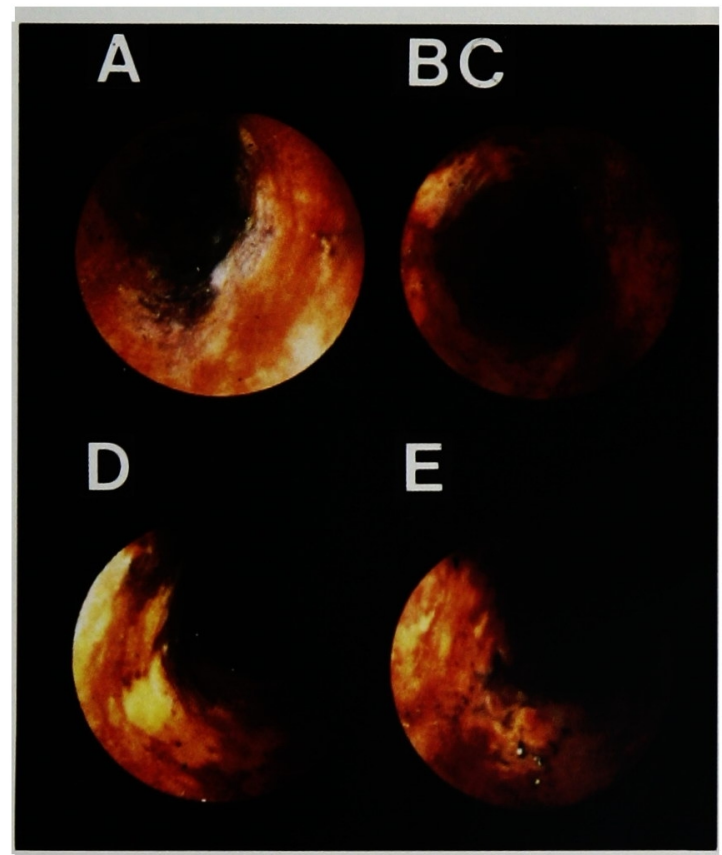

図 3 食道内視鏡トルイジンヨード二重染色法所見 ( $\mathrm{A} \sim \mathrm{E}$ は図 5 と同一部位)

A : 切歯より $23 \mathrm{~cm}$ 後壁混合型表在癌

B C : 切歯上り $28 \mathrm{~cm}$ 前壁, 左側壁平坦型表在癌 D：切歯より $31 \mathrm{~cm}$ 前壁～左側壁平坦型表在癌

$\mathrm{E}:$ 切歯より $35 \mathrm{~cm}$ 左側壁混合型表在癌

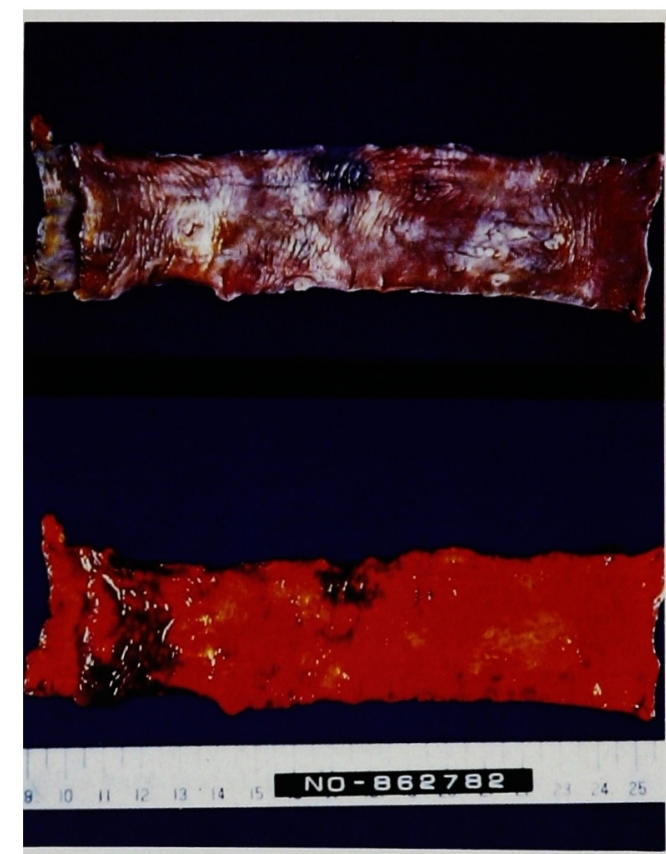

図4 食道切除標本 
輿石晴也・他論文付図（2）

症例：小O良O 48歳, 今 $\left(a_{0}, n_{2}, p l_{0}, m_{0}\right.$, stage III $)$

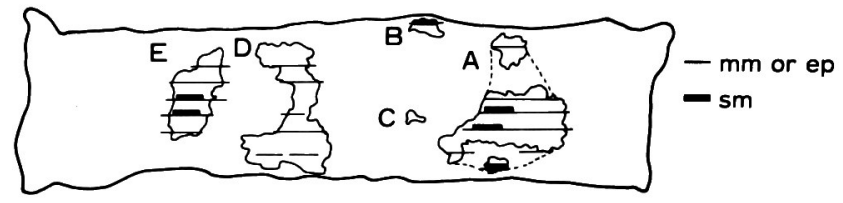

$A \sim C:$ Well differentiated epidermoid carcinoma

D : Moderately differentiated epidermoid carcinoma

E : Poorly differentiated epidermoid carcinoma

图 5 食道切除標本模式図( $A \sim E$ は図 3 と同一部位 $)$

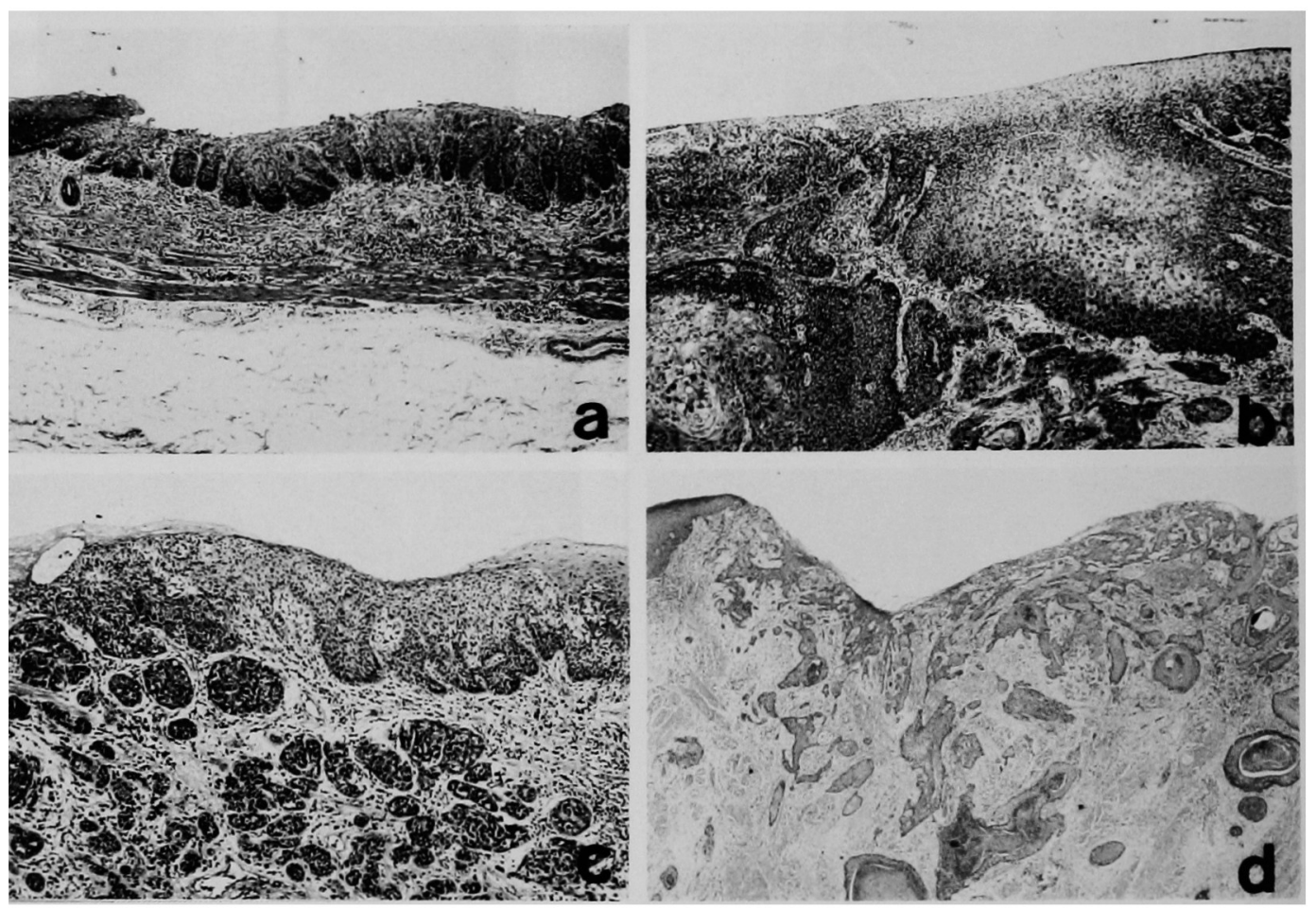

図 6 食道, 舌の病理組織学的所見 ( ( )内 $A \sim E$ は図 3,5 と同一部位)

a (A) : Well differentiated epidermoid carcinoma with submucosal infiltration.

b (D) : Moderately differentiated epidermoid carcinoma with mucosal infiltration.

c (E) : Poorly differentiated epidermoid carcinoma with submucosal infiltration.

d (舌) : Well differentiated epidermoid carcinoma. 
と報告しており, 食道表在癌については遠藤 ら6) は113例中 7 例, $6.2 \%$ に多発癌を認めたと 報告している。ちなみに, 過去 10 年間の当院に おける食道表在癌は27例あるが, このうち 7 例, $26 \%$ が多発癌であり, 表在癌の場合, 多発癌が 多い傾向にある。

このように頭頸部と食道の重複癌や，おのお のの多発癌は決して稀ではないが7ー9)，本症例 のような異時性多発舌癌と, 3 種類の分化の異 なる多発食道表在癌との重複症例は, 本邦では いまだに報告されていない。このような多発癌 の発生機序については, 口腔粘膜から下部食道 まで連続した扁平上皮層に生ずる異形成変化, いわゆる field carcinogenesisによる多中心性 発癌として解釈する報告が見られる 喫煙, 飲酒による外的因子についても検討され ており ${ }^{1,22)}$, 本症例も飲食店経営者であり, 長い 揳煙歴, 飲酒歴を持っている high risk group で あった。

食道表在癌は, 遠藤ら ${ }^{12)}$ は, 食道癌全切除例 約1,000例中64例でしかないと報告しているが その数は増加傾向にある。ちなみに1986年まで の当院の過去 10 年間の食道表在癌切除例は 27 例 あるが, 1985 年 4 例, 1986 年 7 例, と少数なが ら近年増加している。この傾向は近年の食道内 視鏡検査法の進歩によるものと思われる。特に 本症例では色素法の応用が小癌巣の正確な診断 に役立っている。前述のように食道表在癌は多 発癌が多いため, 食道色素内視鏡検查法による 丁寧な精査が必要である。また頭顓部領域癌患 者に対する食道精査も，食道色素内視鏡検査法 を行う必要があると思われる8。

本症例の予後についてみると, 舌癌は治癒手 術が行われているが, 食道癌は $\mathrm{n}_{2}$ であった。根 治手術わよび補助化学療法が行われてはいる が, 再発を起こす可能性がある。また, 残存舌 や残存頸部食道, あるいは他臟器に, 再び異時 性重複癌の発生する可能性も高いと思われる。 このため, 今後の注意深い経過観察が必要であ ろう。

\section{おわりに}

異時性多発舌癌に，同時性多発食道表在癌を
合併した極めて稀な 1 例を経験したので，食道 表在癌, 多発癌, 重複癌について若干の文献的 考察を加えて報告した。

この論文の要旨は,第723回外科集団会においてロ 演した。

\section{文 献}

1) Cahan, W.G., Castro, E.B., Rosen, P.P., et al. : Separate primary carcinomas of the esophagus and head and neck region in the same patient. Cancer, $37: 85-89,1976$.

2 ) 川本誠一, 池田 恢, 西山謹司: 頭頸部癌症例 における重複癌。癌の臨床, $28: 1-7,1982$.

3 ) 阿保七三郎, 三浦秀男, 工藤 保・他：日本に おける食道と他臟器の重複について。日消外会 誌, $13: 377-381,1980$

4 ）喜多みどり, 大川智彦, 後藤真喜子・他：食道 癌における重複癌症例の検討.臨床放射線, 29： 577-582, 1984.

5 ）井手博子, 遠藤光夫：食道癌における壁内転移 と多発癌. 外科 MOOK, 24:128-139, 1982.

6 ) Endo, M., Takeshita, K., and Yoshida, M.: How can we diagnose the early stage of esophageal cancer? Endoscopic diagnosis. Endoscopy, $18: 11-18,1986$.

7 ）多幾山涉, 山口佳之, 佐伯俊昭・他：下咽頭頸 部食道がんにおける食道内がん多発をみた 4 症 例の検討. 癌の臨床 $32,4: 392-400,1986$.

8 ）多幾山涉, 高嶋成光, 森田稔・他：下咽頭癌 に同時性に重複した食道微小癌の 2 例. 胃と腸, 21(10)：1123-1127, 1986.

9 ）小宮善昭, 岩本昌平, 関川嘉昭・他：口腔領域 における重複癌の自験12症例. 日口外会誌, 33(2) : 458-463, 1987.

10) Berg, J.W., Sohottenfeld, D., et al. : Incidence of multiple primary cancers. III. Cancer of the respiratory and upper digestive system as multiple primary cancers. J. Nat. Cancer Inst., $44: 263-274,1970$.

11) Vrabec, D.P. : Multiple primary malignancies of the upper aerodigestive system. Ann. Otol., $88: 864-874,1979$.

12）遠藤光夫, 山田明義, 井手博子 - 他: 食道癌早 期診断の進歩. 消化器外科セミナー, $7: 8-20$, 1982. 